\title{
Thermoreversible Sol-Gel Transition of Low-Molecular Weight Gelling Agent/Polymer Systems $\left[l^{i}\right]$ Dynamic Viscoelasticity of 1,$3 ; 2,4-p, p^{\prime}-$ ditoluyliden Sorbitol/i-PP System
}

by

\author{
Toshiaki Kobayashi $^{* 1}$, Masaoki Takahashi ${ }^{* 2}$, and Takeji Hashimoto*2 \\ *1 Nerw Japan Chemical Co. Ltd., 13 Yoshijima Yakura, Fushimi, \\ Kyoto 612, Japan \\ *2 Department of Polymer Chemistry, Faculty of Engineering, Kyoto \\ University, Kyoto 606, Japan
}

Dynamic viscoelastic responses were explored on isotactic polypropylene (i-PP) melt $\left(\mathrm{Mv}=1.61 \times 10^{5}, \mathrm{Mw} / \mathrm{Mn}=4.4\right)$ and $1 \% 1,3 ; 2,4-\mathrm{p}, \mathrm{p}^{\prime}$-ditoluyliden sorbitol (PDTS)/ i-PP system in order to investigate sol-gel transition of PDTS in polymeric media. The storage modulus $G^{\prime}$ and the dynamic viscosity $\eta^{\prime}$ were obtained as a function of temperature in the cooling process from 250 to $130^{\circ} \mathrm{C}$ for i-PP and from 250 to $150^{\circ} \mathrm{C}$ for PDTS/ i-PP system at angular frequencies of $10^{-1}, 1,10,10^{2} \mathrm{rad} / \mathrm{s}$. The results indicated that $1 \%$ PDTS/i-PP system has a sol-gel transition temperature $T_{\mathrm{fg}}=201^{\circ} \mathrm{C}$, which is identified as the critical temperature for formation of the PDTS percolation network.

The master curves of $G^{\prime}$ and $\eta^{\prime}$ are obtained for the sol and gel regions of $1 \%$ PDTS/ i-PP system assuming the thermorheological simplicity in each region. The master curves for the sol region of $1 \%$ PDTS/i-PP system are found to be nearly identical with those of the bulk i-PP melt. However, they were found to be quite different from those for the gel region, especially at low frequencies (corresponding to the terminal flow region of the sol); the gel exhibited a significant increase of $\eta^{\prime}$ and a plateau in $G^{\prime}$ curve, as well. The loss tangent, $\tan \delta$, for the gel was around 1 in the whole frequency range measured. These results for the gel imply that (i) the PDTS aggregates into a percolation network of a large spatial scale, and that (ii) the association of the dissolved PDTS in the matrix into the networks and the dissociation of the PDTS molecules in the networks into the matrix are in dynamical equilibrium, giving rise to the large $\tan \delta$. A model of the sol-gel transition was presented.

Key words: 1,$3 ; 2,4$-p, $\mathrm{p}^{\prime}$-ditoluyliden sorbitol (PDTS) / Sol-gel transition / Polypropylene / Dynamic viscoelasticity

\section{低分子ゲル化剤/高分子系の熱可逆性ゾル-ゲル転移

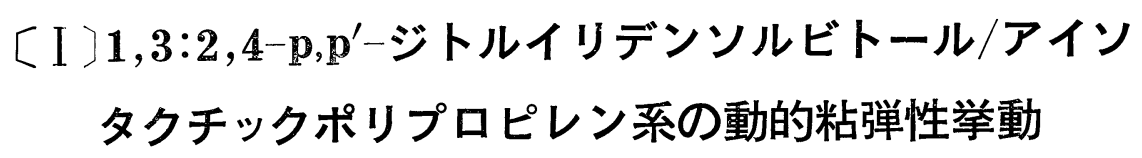

$$
\begin{gathered}
\text { 小 林 稔 明*1 - 高 橋 雅 興*2 - 橋 本 竹 治*2 } \\
\text { (原稿受理 }: \text { 1989年 } 1 \text { 月 } 25 \text { 日) }
\end{gathered}
$$

*1 新日本理化(株)研究所 $\mathbf{7} 612$ 京都市伏見区臀島矢倉町 13

*2 京都大学工学部高分子化学教室 $\mathbf{T} 606$ 京都市左京区吉田本町 


\section{1. 緒言}

我々は近年 $1,3: 2,4-\mathrm{p}, \mathrm{p}^{\prime}$-ジトルイリデンソルビトール（以下, PDTS と略記する) が，広範囲の有機低分子化合物やオリゴマー、 のみならず高分子をむ，数\%以下の少量の添加でゲル化する機能 を有するととを発見した．生成するゲルは熱可逆性であるととよ り, PDTSが「熱可逆性低分子ゲル」に分類される新しいゲル化 剂 (gelling agent) であるととを見いだした1). PDTS/有機溶媒 系および PDTS/オリゴマー系のゾルーゲル転移関しては，落球 試験法によりゾルーゲル転移温度 (以下， $T_{\mathrm{fg}}$ 之略記する) が容 易に求められること，そして PDTS 分子が疑集して形成するゲ ル網目構造の生成熱 $(\Delta H=10.3-26.2 \mathrm{kcal} / \mathrm{mol})$ は，有機溶媒 抒よびオリゴマーの溶解度パラメーター (SP 值) 飞依存し, SP <12.5の範囲では， SP が大きいほど $\Delta H$ が小さな值になること を明らかにした1).

PDTS/高分子系飞おいて, 被ゲル化物である高分子の重合度 $N$ が絡み合い点間の重合度 $N_{\mathrm{e}}$ より大きい場合，その顕著な絡み合

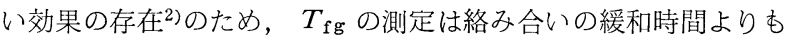
十分長いタイムスケールで行う必要がある。乙のため, 落球試験 法による PDTS/高分子系の正しい $T_{\mathrm{fg}}$ の測定は，必ずしも容易 ではない.一方, PDTSをアイソタクチックポリプロピレン(以下， i-PP と略記する) および低密度ポリエチレンに0.1〜0.5\%溶解 すると, 得られる成形物の光学的性質である透明度および光沢が 顕著に增大する。同時に，少量の PDTS はi-PPまたはポリエチ レンの結晶化の開始温度 $T_{\mathrm{c}}$ と結晶の融解温度 $T_{\mathrm{m}}$ との間の温度 差 $\Delta T=T_{\mathrm{m}}-T_{\mathrm{c}}$ を小さくし，さら汇成形物のヤング率などの力 学的性質を大幅に改質する ${ }^{3)}$. PDTS によるこれらポリオレフィ ンの改質は, PDTS が形成する固有の高次構造と溶融高分子との 相互作用によって, 高分子の結晶核形成速度が促進されて, 結晶 高次組織 (球晶) の微細化が生じたためであると思われる。した がって, PDTS 固有の高次構造の形成之密接な関係にある PDTS /高分子系のゾルーゲル転移に関する研究は, 学術上も工学上む重 要な研究課題であると言える。しかし，乙れまで PDTS/高分子 系のゾルーゲル転移に関する研究論文は皆無である。そこで，本 報では高分子として平均の絡み合い点数 $N / N_{\mathrm{e}}=55$ の i-PP を選 択して，1\% PDTS/i-PP 系について，レオメーターによる動的 粘弹性の測定を行い，高分子系における PDTS のゾルーゲル転移 および転移温度 $T_{\mathrm{fg}}$ の評価について検討した。はじめに，䝪蔵弾 性率 $G^{\prime}$, 損失弾性率 $G^{\prime \prime}$ および動的粘度の実数部 $\eta^{\prime}$ の温度 $T$ 依 存性曲線を幾つかの角周波数 $\omega$ のとで求めた。次に，各温度に おける $G^{\prime}$ および $\eta^{\prime} の \omega$ 依存性を求め, 換算周波数を用いて換算 曲線の作成を試みた。乙れらの解析結果から，1\% PDTS/i-PP 系におけるゾルーゲル転移，および転移に伴う構造変化と動的粘 弾性関数との関係を明らかにした。

\section{2. 実 験}

\section{$2 \cdot 1$ 試料}

PDTS 実験試料は所定の方法 ${ }^{4)}$ とより合成し, 前報1)と同様に精 製して, ガスクロマトグラフィーにより純度 $100.0 \%$ 確認して, 試科として用いた。 i-PP は工業グレードの単独重合体粉末であ り，分別をせずにそのまま試料として用いた。 i-PP のキャラク

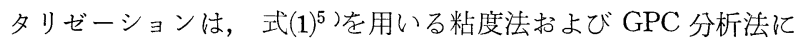

より行った。すなおち, 求めた極限粘度数 $[\eta](\mathrm{dl} / \mathrm{g})$ より, 式 (1)を用いて粘度平均分子量 $M_{\mathrm{v}}=1.61 \times 10^{5}$ を, GPC 分析より分 子量分布に関する不均一指数 $M_{\mathrm{w}} / M_{\mathrm{n}}=4.4$ を得た。

$$
[\eta]=1.10 \times 10^{-4} M_{\mathrm{v}}{ }^{0.8}
$$

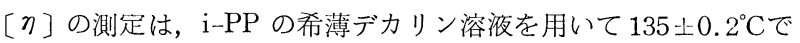
行った.

動的粘弾性測定には次の 2 種類の試料を用いた。すなわち, PDTS を含まない i-PP:単体 (以下, P10 と略記する) および PDTS 濃度 $1 \%$ の-PP (以下, P 15 と略記する) の 2 種類であ る. 測定用試料の成形は, 次のように行った. 所定の割合で秤量 した i-PP およびPDTSを，2軸翼混練機のラボプラストミル [東洋精機(㑣)]を用いて, 樹脂温度 $230^{\circ} \mathrm{C}$, 混練速度 $60 \mathrm{rpm}$ で 5 分間混練した. 乙の時, 酸化防止剂 2,6 -ジーターシャリーブチルヒ ドロキシトルエンと重合触媒残涬の中和剂ステアリン酸カルシウ ムとを，それぞれ0.1および0.05phrいずれの試料にあ添加した。 次に，プレス成形機 [郴神藤金属工業所〕を用いて $230^{\circ} \mathrm{C}$, $150 \mathrm{~kg} / \mathrm{cm}^{2}$ で 5 分間プレス成形して, 室温の水で冷却するととに より，厚み $2 \mathrm{~mm}$ ，直径 $2.5 \mathrm{~cm}$ のディスクを作成した。乙れを動的 粘弾性の測定用試料に供した。

\section{$2 \cdot 2$ 動的粘弾性の測定}

動的粘弾性関数 $G^{\prime}$ および $\eta^{\prime}$ の測定は, Rheometrics Dynamic Spectrometer [Rheometrics Co.], 直径 $2.5 \mathrm{~cm}$ の平行円板を用い て, 温度掃引様式で測定した。すなおち, 正弦振動の角周波数 $\omega$ を $10^{-1}, 1,10,10^{2} \mathrm{rad} / \mathrm{s}$ のいずれかに固定し, 試料を $250^{\circ} \mathrm{C}$ 亿 5 分間保った後に，約 $1{ }^{\circ} \mathrm{C} / \mathrm{min}$ の速度で降温しながら，130または $150^{\circ} \mathrm{C}$ まで $5{ }^{\circ} \mathrm{C}$ 間隔で温度 $T$ の関数として測定した。次の理由に より，測定前に試料を $250^{\circ} \mathrm{C}$ に 5 分間保った。一つは，i-PP の 融点 $170^{\circ} \mathrm{C}$ よ十分高温に保持するととにより，i-PP の結晶を完 全に融解し，元の結晶構造のメモリ一をできるだけ消去する ${ }^{6)}$ めである．屯う一つは，PDTS が完全に溶解したゾル状態を作 るととによって，試料作成時のメモリーを消去するためである.

P 10とP 15とについて，それぞれ130および150Cで測定を停止 した。 その理由は，示差走查熱量計による等温結晶化測定の結果， P 10では $130^{\circ} \mathrm{C}$ 以，P15では PDTS の核剤効果3のために，150 ${ }^{\circ} \mathrm{C}$ 以下の温度で， i-PP の結晶成長が起こる7)ととが判明したか らである。歪 $\Upsilon$ は，全測定領域で線形性の成立する範囲内であ る $\gamma=0.05$ 亿固定した。レオメーターへの試料の装媜に当たって は，測定值の誤差を小さくするため，試料泡が混入しないよう に注意を払った。

\section{3. 結果と考察}

\section{$3 \cdot 1$ 動的粘弾性関数の温度依存性とゾルーゲル転移温度 $\boldsymbol{T}_{\mathrm{fg}}$}

P 10とP15について， $G^{\prime}$ および ク'の温度依存性をそれぞれ Fig. 1 および Fig. 2 亿示した。 P10では, 温度 $T$ が降下する につれて, $\log G^{\prime}$ および $\log \eta^{\prime}$ は共に明確な変曲点を持たず に，なめらかに上昇した。一方 P 15 では，Tが降下するにつれて $\log G^{\prime}$ および $\log \eta^{\prime}$ は共に $200^{\circ} \mathrm{C}$ 近傍の温度領域で顕著な立ち上 がりが生じ，続いておよそ $175>T>140^{\circ} \mathrm{C}$ の温度領域で勾配が緩 やかに上昇した。P15におけるこのような $G^{\prime} ， \eta^{\prime}$ の顕著な立ち上 がりは，PDTSのゲル網目の形成を示唆する，P15において，G $G^{\prime}$ および $\eta^{\prime}$ の急激な立ち上がりが始まる温度 $T_{\mathrm{c}}$ を, 次のように定 
めた。 $200^{\circ} \mathrm{C}$ 付近を境として，それょり高温側および僅かに低温 側の $G^{\prime}$ および $\eta^{\prime}$ のデーターをそれぞれ直線で近似し, 二本の直 線の交点に対応する温度を $T_{\mathrm{c}}$ とした。 $T_{\mathrm{c}}$ は測定した角周波数 $\omega$ の範囲内では $\omega$ によらず一定で, $T_{\mathrm{c}}=201^{\circ} \mathrm{C}$ と求められた。 この ように $T_{\mathrm{c}}$ が $\omega$ に依存しないのは, PDTS の濃度が $1 \%$ と比較的 高いために，実験に用いた降温速度により定まる観測時間尺度に 比し，PDTS のゲル網目の形成速度が十分速いためであると思わ れる。 この $T_{\mathrm{c}}$ を境にして， $T<T_{\mathrm{c}}$ で立ち上がる $G^{\prime}$ および $\eta^{\prime}$ の

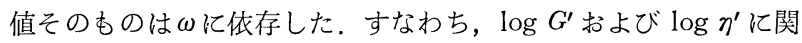
して，P15とP10の差を比較すると， $\omega$ が低いほど差は大きい. 例えば， $\omega$ が比較的低い $\omega=10^{-1} \mathrm{rad} / \mathrm{s}$ のき， $T_{\mathrm{c}}$ 以下の温度で $\mathrm{P} 15$ の $G^{\prime}$ および $\eta^{\prime}$ は，共にP 10 亿比較して約 3 桁程度の上昇が 認められた。このような長時間側の粘弾性関数の顕著な増大は, 大きな空間スケールにわたる構造変化，例えば広範囲にわたるゲ ル網目の形成を示唆する。

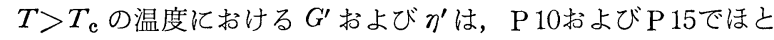

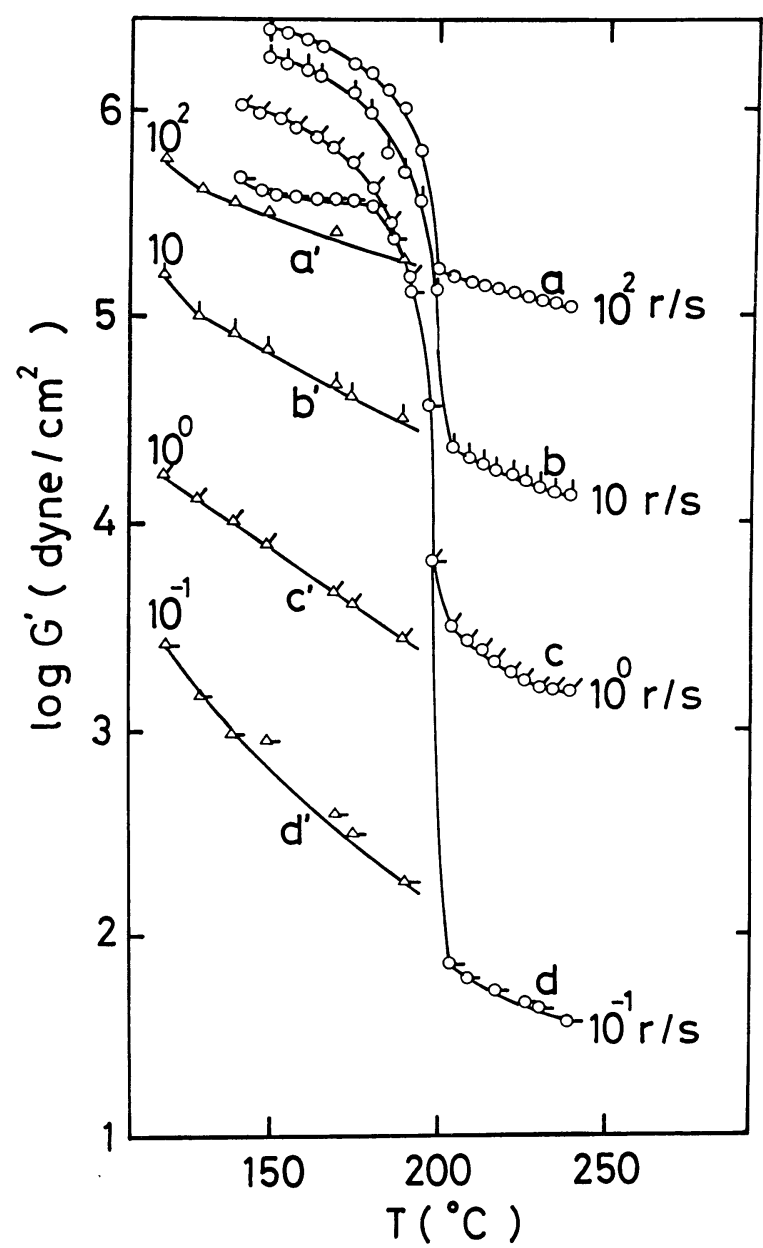

Fig. 1 Temperature dependencies of the storage modulus $G^{\prime}$ which were measured during cooling cycle from 250 to $150^{\circ} \mathrm{C}$ for $1 \%$ PDTS/i-PP system (P15, curves $a$ to $d$ ) and from 250 to $130^{\circ} \mathrm{C}$ for bulk i-PP (P10, curves $a^{\prime}$ to $\left.d^{\prime}\right)$. The strain $\gamma$ is $5.0 \%$. The curves a and $a^{\prime}$ were obtained at $\omega=$ $10^{2} \mathrm{rad} / \mathrm{s} . b$ and $b^{\prime}$ at $\omega=10 \mathrm{rad} / \mathrm{s}, c$ and $c^{\prime}$ at $\omega=1 \mathrm{rad} / \mathrm{s}$, and $d$ and $d^{\prime}$ at $\omega=10^{-1} \mathrm{rad} / \mathrm{s}$.

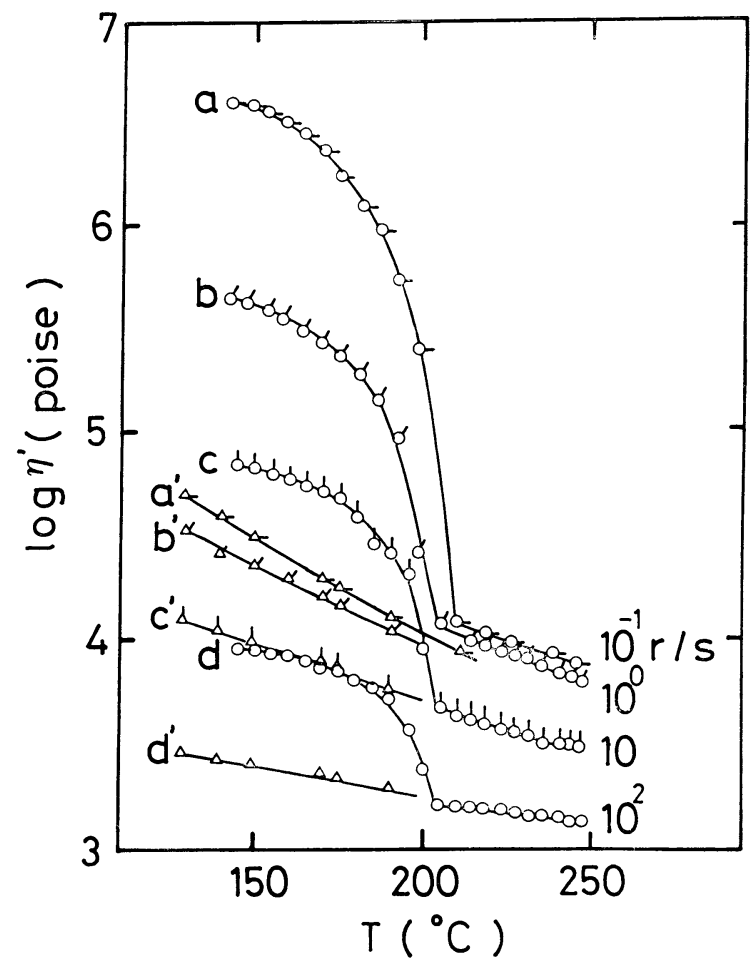

Fig. 2 Temperature dependencies of the dynamic viscosity $\eta^{\prime}$ which were measured during cooling cycle from 250 to $150^{\circ} \mathrm{C}$ for $1 \%$ PDTS/i-PP system (P15, curves $a$ to $d$ ) and from 250 to $130^{\circ} \mathrm{C}$ for bulk i-PP (P10, curves $a^{\prime}$ to $d^{\prime}$ ). The strain $\gamma$ is $5.0 \%$. The curves $a$ and $a^{\prime}$ were obtained at $\omega=10^{-1} \mathrm{rad} / \mathrm{s}, b$ and $b^{\prime}$ at $\omega=10^{\circ} \mathrm{rad} / \mathrm{s}, c$ and $c^{\prime}$ at $\omega=10 \mathrm{rad} / \mathrm{s}$, and $d$ and $d^{\prime}$ at $\omega=10^{-2} \mathrm{rad} / \mathrm{s}$.

んど差は無く，ほぼ同一の值を示した。乙のととょり，T>T では, PDTS の凝集構造は基本的に存在していないと考えてょ い. 有機溶媒やオリゴマーの系と同様に，P15 亿打いて $T \leqq T_{\mathrm{c}}$ $=201^{\circ} \mathrm{C}$ では PDTS の分子間会合によりクラスターが生成し，そ れが発展してパーコレーション構造を形成した1) と予想される. すなわち，P 15 亿衫ける $T_{\mathrm{c}}=201^{\circ} \mathrm{C}$ は, PDTS の分子間会合によ りクラスターの形成が始まる温度であり, 時間の経過につれてク ラスターの発展によりパーコレーション構造が形成されるゾルー ゲル転移温度 $T_{\mathrm{fg}}$ に対応すると考えられる．ただし， $T_{\mathrm{c}}$ 近傍の 恒温ゲル形成過程に扔けるゲル化点の決定 ${ }^{8}$ については別に議論 する.

\section{$3 \cdot 2$ 動的粘弾性関数の重ね合わせ}

P15に打いて, 広範囲にわたりゲル網目が形成されていると示 唆されるおよそ $T<175^{\circ} \mathrm{C}$ の温度領域をゲル部, ゲル網目やPDTS クラスターの存在しない $T>201^{\circ} \mathrm{C}$ の温度領域をゾル部, $T$ 依存 性の大きい中間のおよそ $175<T<201^{\circ} \mathrm{C}$ の温度領域をゾルーゲル 転移領域之呼称するものとする．ゲル形成に伴う粘弾性の変化の 機構を明らかにするために，粘弾性関数の重ね合わせを試みた。 同時にP 10亿対してあ同様の重ね合わせを行った. 重ね合わせを する前に Fig. 1 および Fig. 2 を種々の温度について, $\log G^{\prime}$ vs $\log \omega$ および $\log \eta^{\prime}$ vs $\log \omega$ 亿変換した. 時間-温度換算則2) が成立する温度範囲を明らかにするため，P 15が全温度領域にわ たって熱レオロジー的に単純な系 (thermorheologically simple 
system) であると仮定して，重ね合わせを試みた．

P 15ゾル部のデータが P 10のマスターカーブとできるだけ重な るようにすれば, $\mathrm{P} 15$ ゾル部の $a_{\mathrm{T}}$ が得られるすのとして，その 温度依存性を求めた。 その結果, $\mathrm{P} 15$ ル゙ル部の $a_{\mathrm{T}}$ はP 10 の $a_{\mathrm{T}}$ 之 值がよく似ており，また Arrhenius プロットは後述するように， 良い直線性を示した。ゾル部と P 10 の $a_{\mathrm{T}}$ が良く一致することは, 通常の周波数分散曲線の重ね合わせからあ得られている ${ }^{9)}$. そて で，まず Fig. 3 の右下挿入図で示したゾル部の移動係数 (log $\left.a_{\mathbb{T}}\right)_{\mathrm{S}}$ の温度依存性が，全温度領域にわたって成立するてとを想

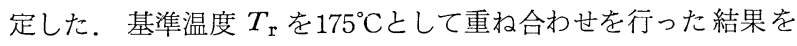
Fig. 3 亿示した．同じ図に，P10亿対する同様の重ね合わせの 結果を示した。 得られた P10のマスターカーブは, 別途測定して 得た $175^{\circ} \mathrm{C}$ における $\mathrm{P} 10$ の $G^{\prime}$ の周波数依存性曲線と一致している ので, 降温下でのP10の動的粘弾性は平衡状態で測定されたと考 えられる. P 15 の $\geqq 205^{\circ} \mathrm{C}$ の温度領域，すなわちゾル部に関し ては時間-温度換算則が適用でき, かつ得られた曲線はP10のマ スターカーブと良く重なった。しかし，P $15 の 150 \leqq T \leqq 200^{\circ} \mathrm{C} の$ 温度領域，すなわち $T_{\mathrm{c}}$ 以下のゾルーゲル転移領域およびゲル部の データーに関しては，P10およびP 15のゾル部が構成する換算曲 線から冕脱して，分岐した 4 本の曲線となった，P15亿関して一 本の曲線が得られなかったので, ゾル部の $\left(\log a_{\mathbb{T}}\right)_{\mathrm{S}}$ の温度依存 性が全温度領域にわたっては成立していないてとになる。すなわ ち、ゾル部とは異なった緩和機構が存在することがわかった。

次に, ゲル部の粘弾性関数の重ね合わせ亿ついて述べる.デー 夕点が少ないので通常の重ね合わせはできないが，ゲル部のデー

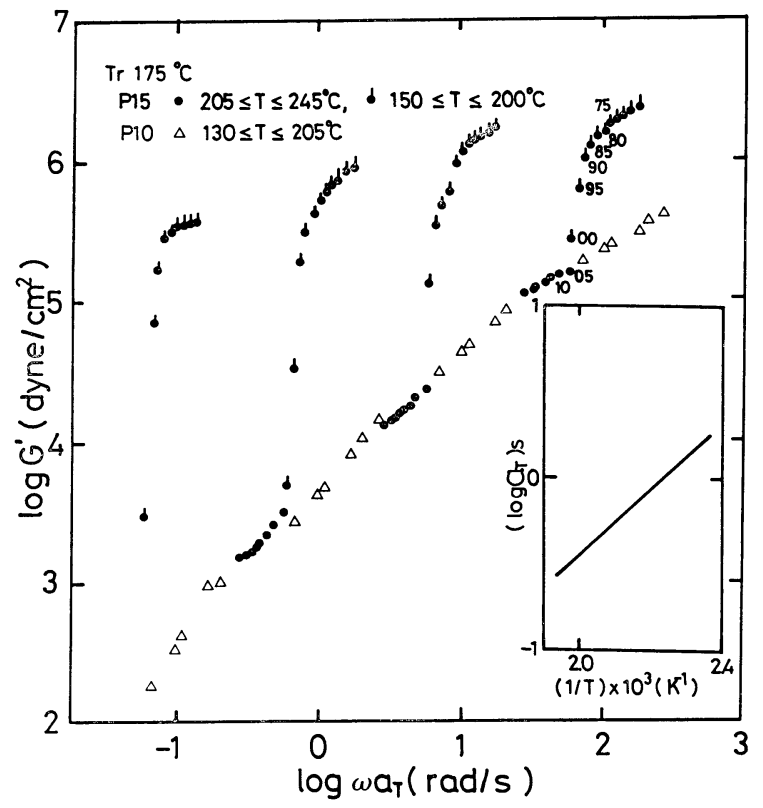

Fig. 3 Time-temperature superposition of the dynamic storage moduli $G^{\prime}$ for $1 \%$ PDTS/i-PP system (circles) and for pure i-PP (triangles) at the reference temperature $T_{\mathrm{r}}=175^{\circ} \mathrm{C}$. The superposition was tried using the temperature dependence of the shift factor appropriate for the sol state as shown in the inserted Figure. The digits 75, $80,85,90,95,00,05$ and 10 indicate the data at temperatures $175,180,185,190,195,200,205$ and $210^{\circ} \mathrm{C}$, respectively.
タをシフトすれば 1 本の曲線が得られるととを想定して $a_{\mathrm{T}}$ を求 めた。 その $a_{\mathrm{T}}$ の温度依存性について Arrhenius プロットすると， 後述するように良い直線性が得られた。 また, 別途測定した通常 の周波数分散曲線の重ね合わせによっても, ゲル部の粘弾性関数 より類似の 1 本のマスターカーブが得られることがわかった9． 芫全な熱平衡下にゲル部の測定はなされていないので, 降温速度 の違いそより全データの一致は無い。しかし，個々の温度依存性 曲線のパターンは一致しており，特にゲル部のデータについては， 降温速度の違いにより大きく異なることが無い。したがって, 今 回の方法で得られた $a_{\mathrm{T}}$ を 15 ゲル部の $a_{\mathrm{T}}$ として, 以下用いた. この $a_{\mathrm{T}}$ の適用範囲を明らかにするために，Fig. 4 の右下挿入 図で示した P 15ゲル部の移動係数 $\left(\log a_{\mathrm{T}}\right)_{\mathrm{G}}$ の温度依存性が, 全 温度領域にわたって成立することを想定した。ゾル部の $a_{\mathrm{T}}$ の適 用の場合之同様にして, ゲル部の $a_{\mathrm{T}}$ を適用して $T_{\mathrm{r}}=175^{\circ} \mathrm{C} し て$ 得られた結果を Fig. 4 亿示した. ゲル部に関しては1本の曲線

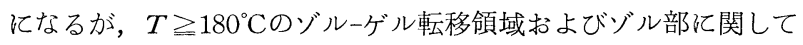
は, ゲル部が構成する 1 本の曲線から逸脱して, 分岐した 4 本の

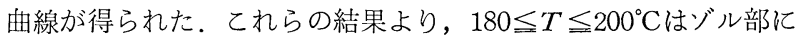
あゲル部にあ属さないゾルーゲル転移領域であるととがわかった。 さらに，ゾル部拉よびゲル部は，各々固有の $a_{\mathrm{T}}$ の温度依存性に 支配されており，両者の動的な力学的性質は明らかに著しく異な っているとと，そしてゾル部およびゲル部は各々熱レオロジ一的 に単純な系として取り扱うことができることがわかった。この熱 レオロジ一的単純性は, 別途測定した周波数依存性曲線の重叔合 わせからあ確認された ${ }^{91}$. また，ゾルーゲル転移領域は種々の温

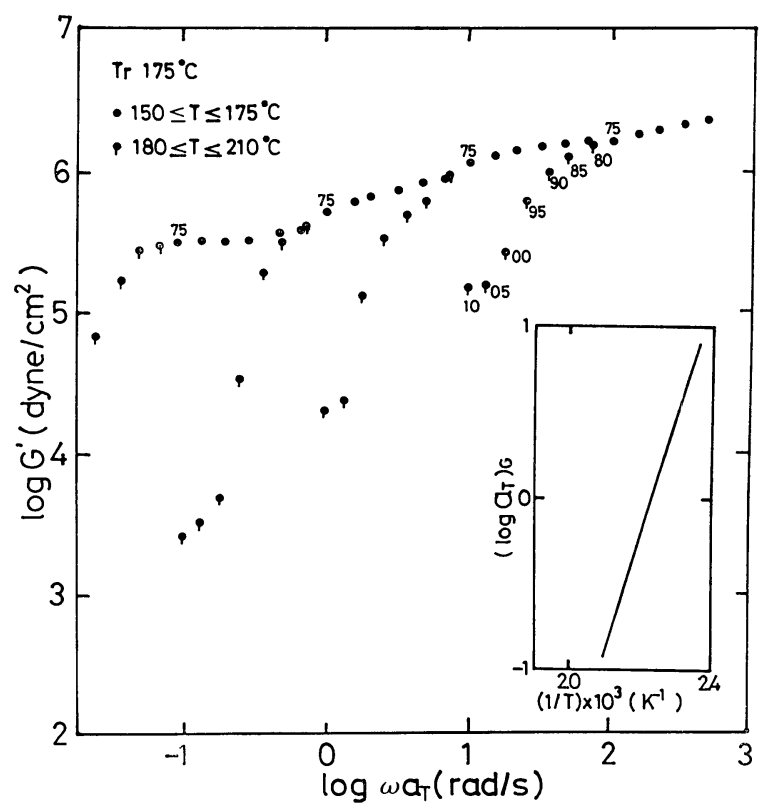

Fig. 4 Time-temperature superposition of the dynamic storage moduli $G^{\prime}$ for $1 \%$ PDTS/i-PP system at the reference temperature $T_{\mathrm{r}}=175^{\circ} \mathrm{C}$. The superposition was tried using the temperature dependence of the shift factor appropriate for the gel state as shown in the inserted Figure. The superpositions of the data at $150 \leqq T \leqq 175^{\circ} \mathrm{C}$ were shown by the symbol and those at $180 \leqq T \leqq$ $210^{\circ} \mathrm{C}$ were shown by the symbol $i$. The digits indicate the same meaning as in Fig. 3. 
度についての $\log G^{\prime}$ vs $\log \omega$ 曲線の重ね合わせの結果, 1 本の 曲線を得ることができなかったので, 熱レオロジ一的に単純な系 として取り扱うことができないことがわかった。

そこで，上記の結果に基づき，ゾルおよびゲル部を区別して， 各々について熱レオロジー的に単純な系として取り扱い，換算果 線の合成を試みた。 $\log G^{\prime}$ vs $\log \omega a_{\mathrm{T}}$ および $\log \eta^{\prime} / a_{\mathrm{T}}$ vs $\log$

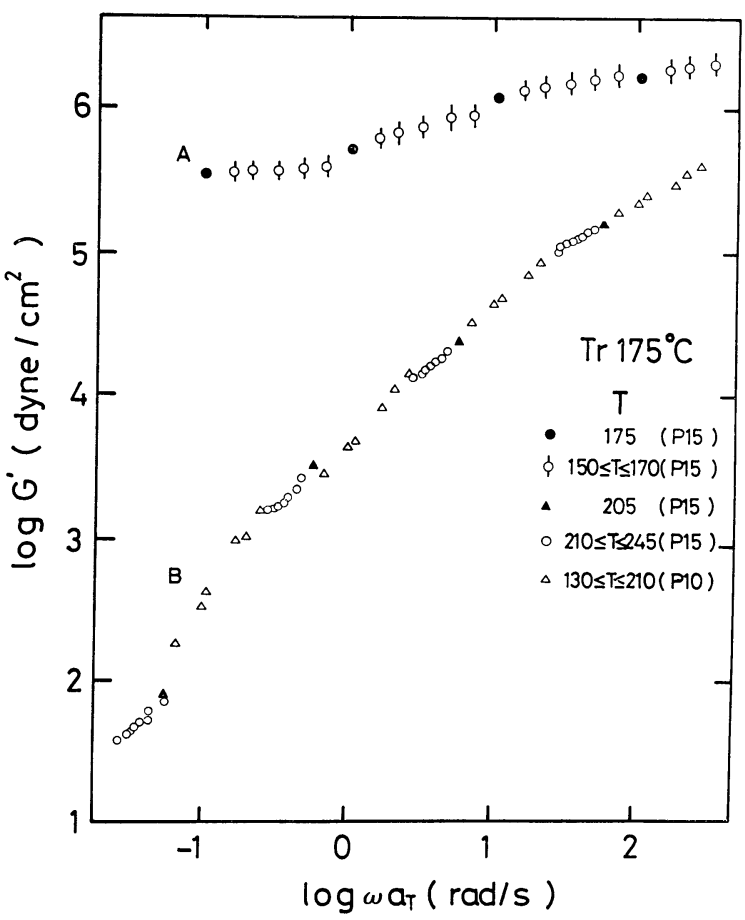

Fig. 5 Master curves of storage moduli $G^{\prime}$ for both sol (curve B) and gel states (curve A) for 1\%PDTS /i-PP system (P15) and for sol state for i-PP bulk (P10) (curve B). The reference temperature $T_{\mathrm{r}}$ is $175^{\circ} \mathrm{C}$. The symbols $(\bullet),(\phi),(\mathbb{N})$ and (O) represent $G^{\prime}$ for $1 \%$ PDTS/i-PP system and $(\triangle)$ for i-PP bulk.

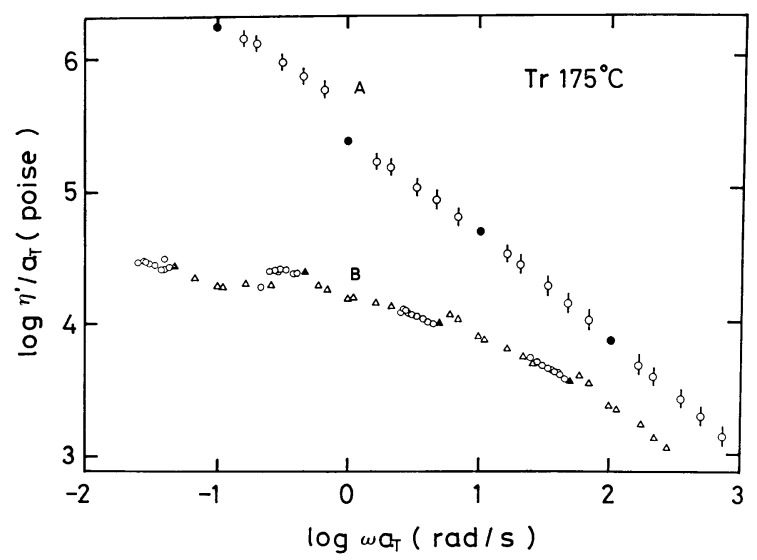

Fig. 6 Master curves of dynamic viscosities $\eta^{\prime}$ for both sol (curve B) and gel states (curve A) for $1 \%$ PDTS/i-PP system (P15) and for sol state for i-PP bulk (P10) (curve B). The reference temperature $T_{\mathrm{r}}$ is $175^{\circ} \mathrm{C}$. Symbols have the same meaning as those for Fig. 5. $\omega a_{\mathrm{T}}$ の換算曲線を，ゾル部求よびゲル部について $T_{\mathrm{r}}=175^{\circ} \mathrm{C}$ と て求めて, 各々 Fig. 5 および Fig. 6 亿示した。ゾル部の曲線 は溶融 i-PP のマスターカーブに良く一致している，乙れは $T>$ $201^{\circ} \mathrm{C}$ では，PDTSがクラスターを形成するととあパーコレーシ ヨンネットワークを形成するととむなく, 分子状に溶解していて, 系がゾル状態にあるためである。 P 10 では $\omega a_{\mathrm{T}}$ が $3 \times 10^{-1}$ 以下の 流動領域で，グがほぼ一定值をとる。乙の領域に打ける $G^{\prime}$ の公 配は約1.4であり，2.0よりかなり小さいが，乙扎はi-PP が多分 散性であるためである ${ }^{10)}$ 之思われる。i-PP の絡み合い点間分子 量 $M_{\mathrm{e}}$ は $M_{\mathrm{e}}=2.9 \times 10^{3}$ であり ${ }^{11)}, \mathrm{P} 10$ の $G^{\prime}$ のマスターカーブは, 弾性率 $G_{\mathrm{N}}{ }^{0}=\rho \mathrm{RT} / M_{\mathrm{e}} \sim 1.1 \times 10^{7} \mathrm{dyne} / \mathrm{cm}^{2}$ 程度のゴム状平坦域 を有しているととになる。しかし，Fig. 5 亿おいてP15のゾルお よびP10が構成するマスターカーブには，測定領域の $\omega$ の範囲で は明確なゴム状平坦域が現われなかった。ての一つの原因として， 試料が $M_{\mathrm{w}} / M_{\mathrm{n}}=4.4$ と広い分子量分布を有する多分散 i-PP であ るので，ゴム状平坦域が緩やかな勾配を持つようになった ${ }^{10) こ と ~}$ が考えられる。

Fig. 5 および Fig. 6 亿おいて， $G^{\prime}$ 於よび グに関するP 15 の ゲル部の曲線とゾル部の曲線とを比較すると， $\omega a_{\mathrm{T}}<1 \mathrm{rad} / \mathrm{s} の$ 周波数領域で，ゲル部の $G^{\prime}, \eta^{\prime}$ は各々二杵ないしは一杵以上ゾル 部よりも大きい。したがって， $\omega a_{\mathrm{T}}<1 \mathrm{rad} / \mathrm{s}$ におけるゲル部の $G^{\prime}$ および $\eta^{\prime}$ は，ほとんど YDTS パーコレーション構造の $G^{\prime}$ お よび ク'の寄与からなり，ゲル構造固有の動的粘弾性関数である 之言える. $\omega a_{\mathrm{T}}>1 \mathrm{rad} / \mathrm{s}$ 周波数領域では， $\omega$ が大きくなる亿つ れて，ゲル部およびゾル部の $G^{\prime}$ および $\eta^{\prime}$ の差は一栴以内に接近 した。したがって， $\omega a_{\mathrm{T}}>1 \mathrm{rad} / \mathrm{s}$ の領域のゲル部の $G^{\prime}$ および $\eta^{\prime}$

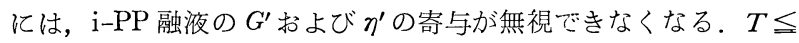
$175^{\circ} \mathrm{C}$ で $G^{\prime}$ および $\eta^{\prime}$ 亿関して，換算曲線が得られたとしてあ良 いと考えられるので，この温度領域においてPDTS網目構造がほ とんど温度飞依存しない屯のと思われる。別途，測定した周波数 分散曲線にもみられたが9)，ゲルの $G^{\prime}$ の換算曲線は低周波数側で 一定値に近づいており，ゲルのク換算曲線は低周波数側で顕著 に増大しているので, PDTS 網目構造は無限大の広がりを有す るであろうととが示唆された。すなおち，乙の温度領域では， PDTS パーコレーションは完結していると考えてあ良いであろう。 さらに，ゲルの損失正接 $\tan \delta=G^{\prime \prime} / G^{\prime}$ は全周波数領域でおよそ 1 亿近いので,PDTS網目構造の網目および網目点におけるPDTS 分子の物理的結合は, 会合と脱会合との動的平衡下にあることが 予想される。

Winter らによる一連の研究 ${ }^{12), 13)}$ によると， $N<N_{\mathrm{e}}$ の反応性高 分子は, 架橋剂との化学反応の進行につれて二ュートン液体から 粘弾性液体となり，パーコレーションネットワークが完結した時 点でゲル化点に到達する，その後は，粘弾性固体からフック弾性 体へと連続的飞変化するとされている. PDTS の物理的会合によ るゲル化の進行は，フック弾性体に到達するかどうかを別にすれ ば，化学的な架橋反応によるゲル化反卮の進行に類似しているむ のと推測される，そこで，以下では彼らの説にしたがってさらに 解析した。

一般に，ゲル化点は極限低周波数における粘度 $\eta_{0}$ の無限大へ の発散と平衡せん断弾性率 $G_{\infty}$ とで定義される ${ }^{12}$. Fig. 5 におい $\tau, \log \omega a_{\mathrm{T}}<0$ 周波数領域では, $G^{\prime}$ が一定值 $G_{\infty}=3.5 \times 10^{5}$ dyne $/ \mathrm{cm}^{2}$ を示す. Fig. 6 亿戈いて, 同じ低周波数領域で $\log \eta^{\prime}$ 
の $\log \omega a_{\mathrm{T}}$ 亿関する勾配 $n$ は $n=-0.65$ であり, 測定範囲内のデ 一ターからは $\eta_{0}=\infty$ が示唆される。したがって，ゲル部は粘弾 性固体的な性質を有しているとしてあ良いであろうと思われる。 ゲル部におけるこの性質は, 彼らの説から PDTS パーコレーシ ョン構造が完結しているためと生じたものと推測される. Fig. 5 において, P 15 の $\log G^{\prime}$ は $\log \omega a_{\mathrm{T}}>0$ の周波数領域で, 緩やか な勾配をもって増加をしている．また Fig. 6 亿おいて，P15の ゲル部の $\log \eta^{\prime}$ は同じ周波数領域で, $\log \omega a_{\mathrm{T}}$ 亿関してほぼ一 定の勾配で減少している．粘弾性関数に対するての領域の緩和機 構の寄与は, PDTS が形成するゲル網目の応答の寄与がかなりの 割合を占めていて，それ亿溶融 i-PP の絡み合いの緩和機構の寄 与が重なってきていると考えられる. PDTS が形成するゲル網目 は, 網目点間の距離と綱目を構成するフィブリルの太さに分布を 有している ${ }^{14)}$. このためゲル網目の $\log G^{\prime}$ は緩やかな勾配をも って増加し, $\log \eta^{\prime}$ は減少し, その結果 Fig. 5 および Fig. 6 の高周波数領域の緩和機構が生じたもの之推測される.

測定全周波数領域で, $\mathrm{P} 15$ ゲル部の $\tan \delta=G^{\prime \prime} / G^{\prime}$ は約 1 であ り, 振動により与えられる力学的エネルギーは, かなりの度合で 散逸した。また，高分子量のザンサンガムの準濃厚水溶液に壏が 添加された系において，分子間会合により形成されるゲルの動的 粘弾性関数の形15)とP15ゲルのそれとは類似していた．乙れら二 つの結果より, PDTS が形成するパーコレーション構造における 網目および網目点の分子間結合は，化学的な永久的な結合ではな く，会合と脱会合とが動的平衡下にあるテンポラリーな物理的結 合であるととが示唆される.

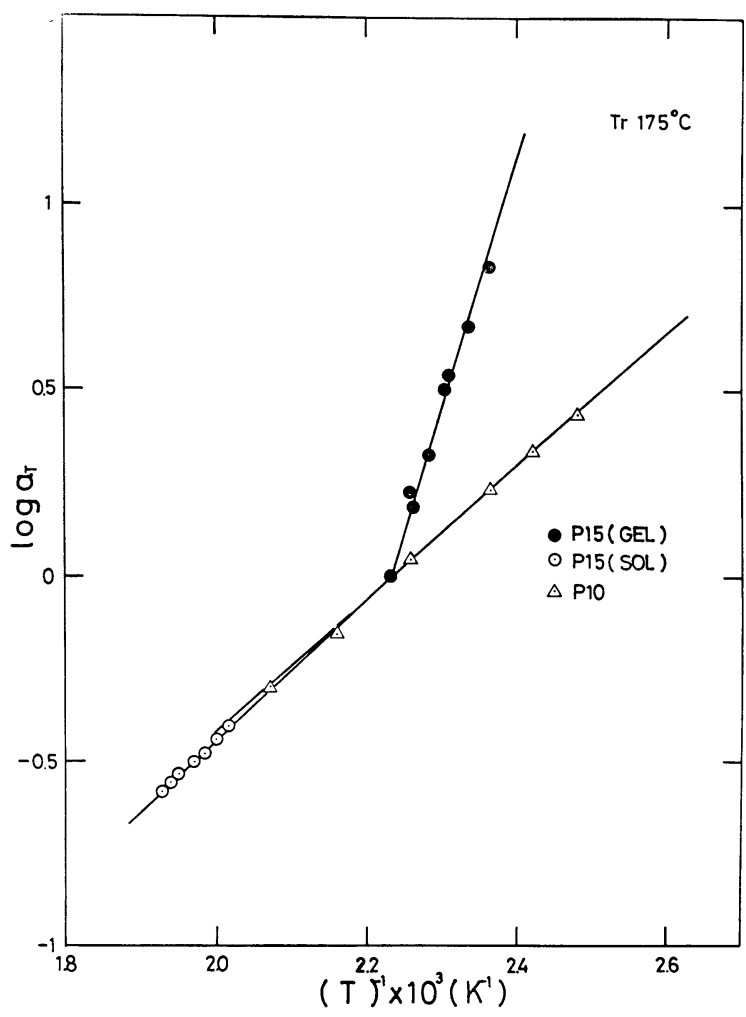

Fig. 7 Temperature dependencies of the shift factors for the gel state of $1 \%$ PDTS/i-PP system ( P15), the sol state of $1 \%$ PDTS/i-PP system $(\odot$ P15) and the sol state of i-PP $(\triangle \mathrm{P} 10)$.
時間-温度重ね合わせの原理を用いて，P10の換算曲線および P 15のゾル部とゲル部の換算曲線を作成した結果より, 各曲線の 移動係数 $\log a_{\mathrm{T}}$ が得られた。移動係数 $\log a_{\mathrm{T}}$ の温度依存性を $1 / T$ 亿対してプロットすると， 3 本の直線が得られた。 そてで, てれらの直線を $T_{\mathrm{r}}=175^{\circ} \mathrm{C}$ して, Arrhenius プロットして Fig. 7 亿示した。 P10の移動係数のプロットは，P15ゾル部の移動係 数のプロットとほぼ一致しており，次式より求まるみかけの活性 化エネルギー $\Delta H_{\mathrm{a}}$ あ各々 8.2 およひ $8.8 \mathrm{kcal} / \mathrm{mol}$ と殆ど等しい. これらの值は, i-PP の $\Delta H_{\mathrm{a}}$ の文献值 8〜10 $\mathrm{kcal} / \mathrm{mol}^{11), 16)}$ と比 較して妥当である.

$$
\ln a_{\mathrm{T}}=\frac{\Delta H_{\mathrm{a}}}{R}\left(\frac{1}{T}-\frac{1}{T_{\mathrm{r}}}\right)
$$

式(2)で， $R$ は気体定数 $(R=1.987 \mathrm{cal} / \mathrm{K} \mathrm{mol})$ である. これに 対して，P15のゲル部の移動係数より求まるみかけの活性化エネ ルギーは, $30.8 \mathrm{kcal} / \mathrm{mol}$ とゾル部の $\Delta H_{\mathrm{a}}$ よりはるかに大きい.

\section{$3 \cdot 3$ PDTS パーコレーションネットワーク形成の機構}

以上の解析結果から推察される PDTS/i-PP 系の降温時のゲル 形成過程を Fig. 8 亿示した. $T>201^{\circ} \mathrm{C}$ の温度領域では, PDTS は溶融 i-PP の動的粘弾性の挙動に殆どなんの影響む及ぼさない. この温度領域では，(A)に示したように PDTS は溶融 i-PP に分子 状に溶解している， $T_{\mathrm{c}}=201^{\circ} \mathrm{C}$ 以下で $175^{\circ} \mathrm{C}$ 以上の温度領域では,

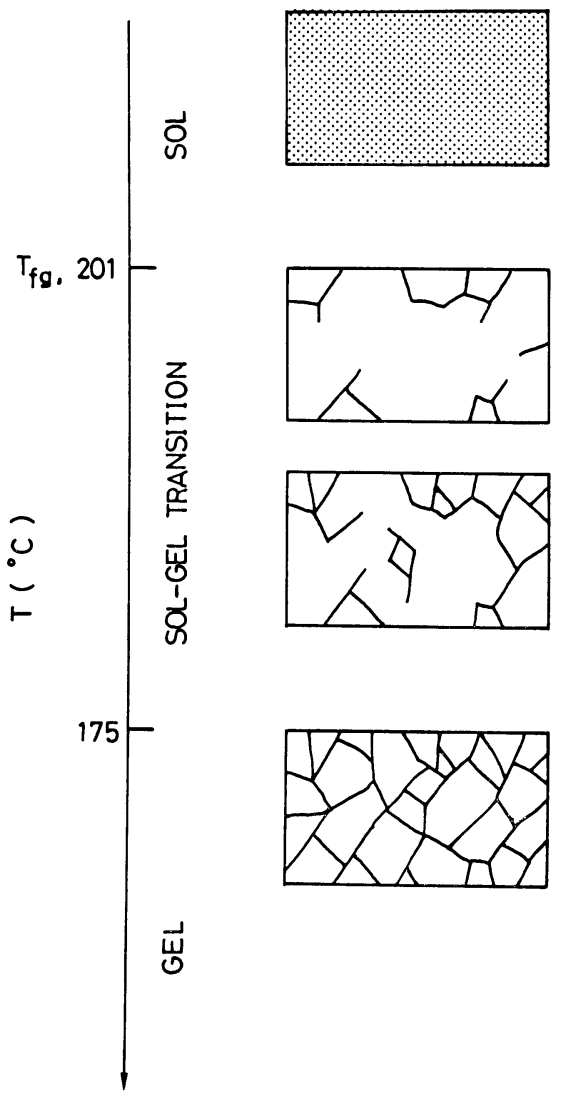

(A)

( B )

( c )

( D )

Fig. 8 Model for the sol-gel transition. The dots in A shematically illustrate molecular dispersion of PDTS molecules in polymeric medium, while the lines in $B, C$ and $D$ indicate intermolecular aggregation of PDTS molecules into networks by physical bonding, most likely hydrogen bonding. 
実験に用いた降温速度に対しては，温度の降下につれて系の動的 粘弾性関数 $G^{\prime}$ および $\eta^{\prime}$ が顕著に大きくなる．乙の領域では，(B) および(C)に示したように，温度の降下につれて PDTS が凝集し て，固有のフィブリル状構造体 ${ }^{14)}$ よりなるクラスターを生成する。 そして，クラスタ一間の結合によって網目構造体が形成されてゆ く，乙の領域は，網目構造体が部分から系全体へと発展してゆく， 網目構造完結への中間過程である. $T \leqq 175^{\circ} \mathrm{C}$ では系の動的粘弾 性関数 $G^{\prime}$ および $\eta^{\prime}$ は, 各々 1 本の換算曲線で表された。 乙の温 度領域ではPDTS パーコレーション構造は完結しており, 架橋 点の位置は変化しても全体の網目密度はあまり変わりがない状態 (D)にある。また， $T \leqq T_{\mathrm{c}}=201^{\circ} \mathrm{C}$ における PDTS パーコレーショ ン構造の形成には時間依存性がある.したがって, 長時間観測す れば $T_{\mathrm{c}}$ 近傍でも PDTS パーコレーション構造の形成を観測する ことが可能であるが，そのメッシュサイズは $175^{\circ} \mathrm{C}$ 以下で観測さ れるゲルのそれとは異なるであろう。

\section{4. 結 論}

平均の絡み合い点数 $N / N_{\mathrm{e}}=55$ のアイソタクチックポリプロピ レンに対して，PDTS濃度 1 または $0 \%$ 系であるP 15 およ゙ P 10の動的粘弾性挙動を測定して解析した結果, 以下のととが明 らかになった。

(1) P 15の $G^{\prime}$ および $\eta^{\prime}$ は，温度の低下と共に $T=201^{\circ} \mathrm{C}$ を境にし て急激に増大する。 顕著である. $T<T_{\mathrm{fg}}$ では, 広範囲の空間スケールにわたるゲル 網目の形成が示唆された。

(2)換算温度を $175^{\circ} \mathrm{C}$ とする P $100 G^{\prime}, \eta^{\prime}$ の $\omega a_{\mathrm{T}}$ に関する換算曲線 と $\mathrm{P} 15$ ゾル部の $G^{\prime}, \eta^{\prime}$ の換算曲線とは各々良く一致した。乙れよ り PDTS はP 15ゾル部で分子状に溶解していて, 系の動的粘弹 性関数には殆ど影響を及ぼさないてとが明らかになった。

(3) $T_{\mathrm{r}}$ を $175^{\circ} \mathrm{C} と し て ， P 15 ケ ゙ ル$ 部の換算曲線を作成することがで きた。それはゾル部の換算曲線とは著しく異なっていた。 $\omega a_{\mathrm{T}}<$ $1 \mathrm{rad} / \mathrm{s}$ で，ゲル部の $G^{\prime}$ および $\eta^{\prime}$ は二妳ないしは一桁以上ゾル 部よりあ大きく, $\omega a_{\mathrm{T}}>1 \mathrm{rad} / \mathrm{s}$ では $\omega$ が大きくなるにつれて， ゲル部拉よびゾル部の $G^{\prime}$ および $\eta^{\prime}$ の差は一桁以内に接近した。 このことより $\omega a_{\mathrm{T}}<1 \mathrm{rad} / \mathrm{s}$ の領域のゲル部の $G^{\prime}$ および $\eta^{\prime}$ は, 殆ど PDTS パーコレーション構造の寄与からなり, ゲル構造固 有の動的粘弾性関数であるととが判明した。 $\omega a_{\mathrm{T}}>1 \mathrm{rad} / \mathrm{s}$ の領

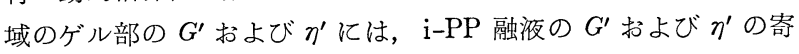
与が加わる。

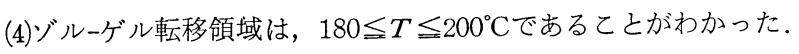
(5)ゲル部の $G^{\prime}$ および $\eta^{\prime}$ は, 各々 1 本の換算曲線で表された。 $T$ $\leqq 175^{\circ} \mathrm{C}$ では PDTS パーコレーション構造は完結しており, 架橋 点の位置が変化して屯全体の網目密度は $T$ に対してあまり変化し ない状態であることが示唆された。

(6)移動係数の Arrhenius プロットの勾配より，1\% PDTS/i-PP 系のゲル部とゾル部および i-PP 融液のみかけの活性化エネルギ 一は, 各々 $30.8,8.8,8.2 \mathrm{kcal} / \mathrm{mol}$ と求まった.

(7)測定全周波数領域で P 15ゲル部の損失正接 $\tan \delta$ は約 1 であ り, 振動により与えられる力学的エネルギーは, 網目および網目 点の分子間結合の会合と脱会合により, かなりの度合で散逸する ことが明らかになった。

以上の解析結果から， P 15飞扔いて $T<T_{\mathrm{c}}=201^{\circ} \mathrm{C}$ 亿温度降下
することによって, PDTS の分子間会合により PDTS クラスタ 一が生成し発展し, パーコレーション構造が形成したと考えられ る. P 15 における $T_{\mathrm{c}}=201^{\circ} \mathrm{C}$ は, PDTS の分子間会合によりクラ スターの形成が開始する温度であり, 時間の経過飞つれてクラス ターの成長発展によりパーコレーション構造が形成されるゾルー ゲル転移温度 $T_{\mathrm{fg}}$ 亿相当する。すすなわち, PDTS/i-PP 系のゲル 化は有機溶媒やオリゴマーの系の場合と同様に, PDTSがパーコ レーションネットワークを形成するてとにより生じ，乙のため系 は明白なゾルーゲル転移温度 $T_{\mathrm{fg}}\left(=201^{\circ} \mathrm{C}\right)$ を有するてとが明ら かになった。また，PDTS が形成するパーコレーション構造によ る網目構造の結合は, 化学的な永久的な結合ではなく, 会合と脱 会合とが動的平衡下にあるテンポラリーな物理的結合であるとと を推論した。

謝辞 本研究に際して, 東燃石油化学株式会社研究所主任研究 員池田忠夫氏に，レオメーターによる測定に御協力いただいたて とを感謝致します。また，論文の発表を許可いただきました新日 本理化株式会社村井孝一会長および北村誠男取締役研究所長に深 謝致します。

\section{文献}

1）小林稔明, 長谷川博一, 橋本竹治, 日本レオロジー学会誌, 17, 86 (1989).

2) Ferry, J.D., "Viscoelastic Properties of Polymers", 3rd Ed. (1980), John Wiley \& Sons, New York.

3) 小林稔明, 野辺富夫, 日本特許 1023186,1023190 ; Kobayashi, T., et al., USA, Patent, 4,532, 280 ; 小林稔明, 長谷川博一, 橋本竹治, 投稿予定.

4) 小林稔明, 藤谷貫剛, 村井孝一, 日本特許 1192099, 1192096 ; USA, Patent, 4,429, 140.

5) Kinsinger, J.B., and R.E. Hughes, J, Phys, Chem., 63, 2002 (1959).

6) 例えば, Majer, J., Kunstoffe, 50, 565 (1960).

7) Kobayashi, T., H. Hasegawa, and T. Hashimoto, Preprints First European Conference High Performance Addtives, London, pp. 62 (1988); to be published.

8) Kobayashi, T., and T. Hashımoto, to be published.

9) Kobayashi, T., M. Takahashi, and T. Hashimoto, 日本 レオロジー学会誌, 投稿中.

10) Masuda, T., K. Kitagawa, T. Inoue, and S. Onogi, Macromolecules, 3, 116 (1970).

11) Pearson, D.S., L. J. Fetters, L. B. Younghouse, and J.W. Mays, Macromolecules, 21, 478 (1988).

12) Winter, H.H., and F. Chambon, J. Rheology, 30, (2), 367 (1986).

13) Hess, W., T. A. Vilgis, and H. H. Winter, Macromolecules, 21, 2536 (1988).

14) Kobayashi, T., H. Hasegawa, and T. Hashimoto, to be published.

15) Rochefort, W.E., and S. Middleman, J. Rheology, 31 (4), 337 (1987).

16) Fujiyama, M., and H. Awaya, J. Appl. Polym. Sci., 16, 275 (1972). 